\title{
Radiopharmaceuticals for Imaging Chronic Lymphocytic Inflammation
}

\author{
Gaurav Malviya ${ }^{1}$, Erik F.J. de Vries ${ }^{1}$, Rudi A. Dierckx ${ }^{1}$ and Alberto Signore ${ }^{1,2 *}$ \\ ${ }^{I}$ Department of Nuclear Medicine and Molecular Imaging, University Medical Center Groningen, University of \\ Groningen, Groningen, The Netherlands. ${ }^{2}$ Nuclear Medicine Unit, II Faculty of Medicine and Surgery, 'Sapienza' \\ University of Rome, St. Andrea Hospital, alberto.signore@uniromal.it; Via di Grottarossa 1035, 00189 - Rome - \\ Italy
}

\begin{abstract}
In the last few decades, a number of radiopharmaceuticals for imaging inflammation have been proposed that differ in their specificity and mechanism of uptake in inflamed foci as compared to the traditional inflammation imaging agents. Radiolabelled cytokines represent a reliable tool for the preclinical diagnosis of chronic inflammatory processes, even before anatomical and functional changes occur in affected tissues. Moreover, the introduction of radiolabelled monoclonal antibodies and sophisticated technique like PET/CT now make the field of inflammation imaging highly specific and accurate. In this review, different approaches of the established and experimental radiopharmaceuticals for imaging of chronic inflammation are discussed.
\end{abstract}

Key words: Radiopharmaceuticals, Inflammation, Molecular Imaging

\section{INTRODUCTION}

Diseases with chronic inflammations are always prominent in clinical medicine and characterised by a wide range of histopathological features. Clinicians frequently face problems in diagnosis and therapy dealing with patients of presumed or established inflammatory disorders, radiopharmaceuticals play a major role in providing the best possible solutions. In last few decades, a large number of radiopharmaceuticals are developed for the imaging of infection and inflammation. Radiopharmaceuticals used for scintigraphic imaging locate the site of acute/chronic infection and inflammation in their early phases. Infection specifically refers to the invasion of malignant micro-organisms, whereas inflammation is the response of the immune system against any type of disorder or injury. There may be inflammation without infection or infection without inflammation depending upon the cause of the disease or injury. Chronic lymphatic inflammation are characterised by infiltration of lymphomononuclear cells in the target organ, whereas acute inflammation have a predominant neutrophil infiltration. It is possible to distinguish different cellular infiltrates for chronic inflammation characterised by a prevalence of cellular immunity (Th1 lymphocytes and monocytes) or humoral immunity (Th2 and B lymphocytes) (Signore et al., 2000). The mechanism of localisation of radiopharmaceutical in lymphocytic inflammation imaging varies; nonspecific radiopharmaceuticals (such as ${ }^{67} \mathrm{Ga}$-citrate and ${ }^{99 \mathrm{~m}} \mathrm{Tc}-\mathrm{HIG}$ ) accumulation depends upon the enhanced transudation, increased vascular

\footnotetext{
${ }^{*}$ Author for correspondence
} 
permeability and increased blood supply processes whereas uptake of specific radiopharmaceuticals (such as ${ }^{99 \mathrm{~m}} \mathrm{Tc}-\mathrm{mAbs},{ }^{99 \mathrm{~m}} \mathrm{Tc}$-cytokines) depends upon the antigen-antibody interaction or a specific receptor binding process. Non-specific radiopharmaceutical accumulation is due to processes that are common in infection and inflammation and therefore it can not distinguish between infection and inflammation. In this respect, it should be noted that all the radiopharmaceuticals accumulate to some extent in the inflamed area due to increase blood supply and vascular permeability. For the specific detection of infection and inflammation different radiopharmaceuticals demonstrate different levels of accuracy in their sensitivity and specificity according to the pathophysiology and pathobiochemical process of individual disease.

This review will focus mainly on the established and routinely available radiopharmaceuticals for chronic lymphocytic inflammation, although it will also deals with potential radiopharmaceuticals for the future.

\section{No Ideal Radiopharmaceutical}

Typical characteristics for an ideal radiopharmaceutical have been defined by different authors (Rennen et al., 2001; BleekerRovers et al., 2004; Bernardo-Filho et al., 2005, Buscombe, 2006). Although, no radiopharmaceutical has been discovered till now that fulfils all the characteristics of an ideal one, each has its own advantages and disadvantages. However, in the present scenario, we especially need more specific and sensitive radiopharmaceuticals for the diagnosis of infection and inflammation, which can specifically detect the level of different activation markers, adhesion molecules and receptors. The information these radiopharmaceuticals can provide could be used for the therapy decision making and to detect the response to the therapy. Conti et al. (2005) have shown the use of radiolabelled anti-TNF $\alpha$ monoclonal antibody as a prognostic tool for arthritis and suggest that the selection of patients who are the candidates for innovative anti-TNF $\alpha$ intra articular therapy should be guided by antiTNF $\alpha$ scintigraphy.

Some radiopharmaceuticals also have the potential to distinguish between infection and inflammation, as advancement in the molecular imaging field, radiolabelled antibiotics are developed which are highly specific for the microbial infection rather than sterile inflammation (Benitez et al., 2006). In two different studies, Venjamuri et al. (1996) using ${ }^{99 m}$ Tc-Ciproflaxacin and Benitez et al. (2006) using ${ }^{99 \mathrm{~m}}$ Tc-Certizoxime antibiotics show their diagnostic specificity for the infection foci that could differentiate sterile from septic inflammation.

In this way, the research is now more focused on the development of particular tracers with more accuracy, sensitivity and specificity profile for the investigation of a particular infection or inflammation rather than searching for any ideal agent.

\section{Radiolabelled Antibodies}

Radiolabelled antibodies can be of following two kinds:

\section{Radiolabelled Human Polyclonal Immunoglobulin G}

Human polyclonal immunoglobulin (HIG) is a non antigen specific IgG antibody that can be labelled with ${ }^{99 \mathrm{~m}} \mathrm{Tc}$, having a half-life of 6 hours and 140 $\mathrm{keV}$ energy. It can also be labelled with ${ }^{111}$ In for imaging at the time points beyond the 24 hours. The advantages of ${ }^{99 \mathrm{~m}} \mathrm{Tc}$ over ${ }^{111} \mathrm{In}$ are its low radiation exposure, easy availability, short half-life and low price. Since HIG is of human origin, it does not produce any allergic response. The accumulation of radiolabelled HIG at the site of inflammation is non-specific and is related to the increase in vascularization, extracellular fluid volume and endothelial permeability within the inflamed site (Corstens et al., 1993).

A study was performed by Nijhof et al. (1997), in the patients with different infections and inflammation using ${ }^{111}$ In- labelled non-specific immunoglobulin. In this study, 226 patients underwent the scintigraphy examination for 232 possible infection or inflammation foci. Imaging was performed $4 \mathrm{~h}, 24 \mathrm{~h}$ and $48 \mathrm{~h}$ post injection. The conclusion of the study was that ${ }^{111} \mathrm{In}$ - labelled non-specific immunoglobulin scintigraphy is a very sensitive tool for detection of infectious and inflamed bone and joint disorders. Another study reported that the ${ }^{99 \mathrm{~m}} \mathrm{Tc}$ - non-specific immunoglobulin scintigraphy is more specific for detecting synovitis in comparison with ${ }^{99 \mathrm{~m}} \mathrm{Tc}$ diphosphonate (Bois de et al., 1995). A study was performed by Cindas et al. (2001) to investigate whether ${ }^{99 \mathrm{~m}} \mathrm{Tc}$ labelled polyclonal human immunoglobulin $\left({ }^{99 \mathrm{~m}} \mathrm{Tc}-\mathrm{HIG}\right)$ scintigraphy detects 
synovial inflammation in the patients with rheumatoid arthritis (RA). 29 patients with active RA underwent the scintigraphic examination and a total of 928 joints were evaluated for active inflammation. The authors concluded that the ${ }^{99 \mathrm{~m}} \mathrm{Tc}-\mathrm{HIG}$ uptake correlates with active inflammation and in RA it reflects the synovial inflammation specifically and distinguishes joints with and without inflammation.

Recently, Ortapamuk et al. (2002) performed a study to clarify whether ${ }^{99 \mathrm{~m}} \mathrm{Tc}-\mathrm{HIG}$ can detect and determine the severity of orbital involvement in patients with Graves' ophthalmopathy. Planar and SPECT examination were performed 4 hours after the injection of ${ }^{99 \mathrm{~m}} \mathrm{Tc}-\mathrm{HIG}$ in 26 patients with Graves' ophthalmopathy. In this study, it was concluded that ${ }^{99 \mathrm{~m}} \mathrm{Tc}-\mathrm{HIG}$ can clearly identify patients with clinically active inflammation, but also subclinicial inflammation can be seen by ${ }^{99 \mathrm{~m}}$ Tc-HIG scintigraphic evaluation.

These studies demonstrate that the ${ }^{99 \mathrm{~m}} \mathrm{Tc}-\mathrm{HIG}$ could not only be used for the assessment of disease activity but also as an effective prognostics tool for the inflammation mediated disorders.

\section{Radiolabelled monoclonal antibodies}

In last decade, radiolabelled monoclonal antibodies (mAbs) and their Fab' fragments were developed as a new class of radiopharmaceuticals for radioimmunoscintigraphy. These radiolabelledmAbs allow the excellent molecular imaging of inflammation and infection in several immunemediated disorders by binding with highly specific receptors expressed on particular sub cell population.

\section{Anti-TNF $\alpha$ Antibodies}

\section{${ }^{99 m}$ Tc-Infliximab}

Infliximab $\left(\right.$ Rimicade $\left.^{\circledR}\right)$ is a chimeric $\operatorname{IgG1\kappa }$ monoclonal antibody (MoAb), with a murine variable $(\mathrm{Fv})$ domain of mouse anti-human TNF- $\alpha$ antibody and constant $(\mathrm{Fc})$ sequences of human IgG1. Infliximab is produced by recombinant cell culture techniques. It specifically recognizes and binds to both soluble and membrane-bound TNF- $\alpha$ with high avidity and high affinity $\left(K \mathrm{a}=10^{10} \mathrm{M}^{-1}\right)$ (Knight et al., 1993).

Infliximab is labelled with ${ }^{99 \mathrm{~m}} \mathrm{Tc}$, using a direct radiolabelling method (Annovazzi et al., 2002). A ${ }^{99 \mathrm{~m}}$ Tc-Infliximab scintigraphic study was successfully performed by Conti at al. (2005) to assess the degree of TNF- $\alpha$ mediated inflammation in the affected knees in patients with active rheumatoid arthritis. Scintigraphy showed the intense accumulation of ${ }^{99 \mathrm{~m}} \mathrm{Tc}$-infliximab in the affected knee which represents the high levels of intralesional TNF- $\alpha$, interestingly they did not find uptake in the unaffected joints.

Another pilot study was performed by Chianelli et al. (2006) on seven rheumatoid arthritis (RA) patients. In this study, nine inflamed joints were examined with ${ }^{99 \mathrm{~m}}$ Tc-infliximab scintigraphy. Post-treatment scintigraphy demonstrated the different amounts of radiopharmaceutical uptake in the inflamed joints; 3 inflame joints showed significant changes in uptake, whereas in the other 4 joints uptake was slightly reduced and was unchanged in 2 joints. Moreover, these imaging results affected clinical treatment.

Recently, we have performed a study with ${ }^{99 \mathrm{~m}} \mathrm{Tc}$ labelled infliximab in the patients with active Crohn's Disease (CD), to investigate in-vivo biokinetics of anti-TNF- $\alpha$ antibodies and to predict the clinical response of anti-TNF $\alpha$ therapy (D'Alessandria et al., 2007). Scintigraphic scanning with ${ }^{99 \mathrm{~m}} \mathrm{Tc}$-Infliximab allowed us to visualize in vivo the intestinal sites where TNF- $\alpha$ was present. In this study, we found little TNF- $\alpha$ in the affected bowel of patients with active CD. Therefore, we concluded that, the clinical benefit that patients have from anti-TNF- $\alpha$ therapy is unlikely the consequence of a local a reduction of TNF- $\alpha$. The mechanism of action, in therapeutic doses, therefore deserves further investigation.

These preliminary studies in humans showed the specific targeting of this radiopharmaceutical in the inflamed foci. Moreover, these studies also demonstrate that the selection of the candidates for infliximab therapy and prediction of therapy response could be possible by using ${ }^{99 \mathrm{~m}} \mathrm{Tc}-$ infliximab scintigraphy before initiating anti-TNF therapy.

\section{${ }^{99 m}$ Tc-Adalimumab}

Adalimumab (Humira ${ }^{\circledR}$ ) is the first 'fully human' recombinant monoclonal IgG1 antibody against TNF- $\alpha$. It is engineered through the phase display technology in a Chinese Hamster Ovary (CHO) mammalian expression system. It recognizes both soluble and membrane-bound TNF- $\alpha$ with high specificity and high affinity $\left(\mathrm{K}_{\mathrm{D}}=6 \times 10^{-10} \mathrm{M}\right)$ and inhibits its biological activity by blocking interaction with $\mathrm{p} 55$ and p75 cell surface TNF 
receptors (Rau, 2002). It can also lyse TNFexpressing cells in the presence of complement.

Adalimumab was radiolabelled with ${ }^{99 \mathrm{~m}} \mathrm{Tc}$, using an indirect radiolabelling method as described by Abrams et al. (1990). A scintigraphic imaging study was successfully performed by Barrera et al. (2003) to assess the sensitivity and biodistribution of systemically administered ${ }^{99 \mathrm{~m}}$ Tc-Adalimumab in ten patients with active RA. All the patients underwent two scintigraphic examinations, first to assess the biodistribution of the radiolabelled antibody and second after two weeks to assess the specificity for TNF targeting and sensitivity to reflect decreased inflammation after the administration of systemic corticosteroids. Each patient received a sub-therapeutic intravenous dose of ${ }^{99 \mathrm{~m}} \mathrm{Tc}$-anti-TNF mAb, prior to scintigraphy. The results demonstrate that the inflamed joints imaged using ${ }^{99 \mathrm{~m}}$ Tc-Adalimumab were clearly visualized at $4 \mathrm{~h}$ and $24 \mathrm{~h}$ after injection and the increase in uptake at $20 \mathrm{~h}$ was $20 \%$ to $30 \%$. Interestingly, no uptake of the ${ }^{99 \mathrm{~m}} \mathrm{Tc}$-Adalimumab was seen in the normal joints. Furthermore, this study shows that the radiopharmaceutical specifically targets to TNF in the arthritic joint and it can detect clinical relevant changes in disease activity. Therefore, ${ }^{99 \mathrm{~m}} \mathrm{Tc}$ labelled human anti-TNF mAb allows clear visualization of the inflamed joints in patients with active rheumatoid arthritis (RA). Joint localization and radiopharmaceutical retention is due to specific TNF targeting in synovitis.

\section{Anti-E-selectin}

E-selectin is an endothelial-specific, cytokineinducible adhesion molecule (Bevilacqua, 1993), which is exclusively expressed on the luminal surface of vascular endothelium during the inflammatory response. Its expression has been demonstrated by immunohistochemistry in a variety of acute and chronic inflammatory diseases, including RA (Mason et al., 1994). Eselectin plays a key role in the inflammatory process; it mediates neutrophils, monocytes and eosinophil adhesion to activated vascular endothelium via carbohydrate ligands such as sialyl Lewis X (Bevilacqua et al., 1989; Bhushan et al., 2002).

As it is well known that, the expression of Eselectin on endothelial cells is induced after stimulation by interleukin-1 (IL-1), TNF or lipopolysaccharide, it is not expressed by resting endothelial cells. Moreover, the increased expression of E-selectin has been detected in several inflammatory disorders (Bevilacqua and Nelson, 1993). A monoclonal antibody against Eselectin labelled with ${ }^{111}$ In and has successfully been used for imaging of inflammation in an animal model (Jamar et al., 1995), thereafter also in humans (Chapman et al., 1996).

Keelan et al. (1994), performed an in vivo study in an animal model with ${ }^{111}$ In-labelled anti-E-selectin monoclonal antibody (1.2B6), to assess the imaging potential of the antibody. The accumulation of intravenously injected ${ }^{111} \mathrm{In}$ labelled $\mathrm{mAb}$ was compared to that of ${ }^{111}$ In-control antibody in a model of arthritis in the pig. This study demonstrated higher accumulation of ${ }^{111} \mathrm{In}$ anti-E-seletin antibody in the synovitis and the authors concluded that radiolabelled anti-Eselectin $\mathrm{mAb}$ can be used to image localized inflammatory tissue.

A comparative study was also performed by Jamar et al. (1997), between ${ }^{99 \mathrm{~m}} \mathrm{Tc}-\mathrm{HIG}$, an established tracer for arthritis imaging, and ${ }^{111}$ In-labelled antiE-selectin $\mathrm{mAb}(1.2 \mathrm{~B} 6)$ in 11 patients with active RA. In this study, net ${ }^{111}$ In counts in the joints increased significantly between $4 \mathrm{~h}$ and $24 \mathrm{~h}$ with a mean change of $54 \pm 40 \%$. Moreover, the images obtained from ${ }^{111}$ In-labelled anti-E-selectin $\mathrm{mAb}$ demonstrates much less vascular activity than with ${ }^{99 \mathrm{~m}}$ Tc-labelled non-specific immunoglobulin and the study reveals that radioimmunoscintigraphy using ${ }^{111}$ In-labelled anti-E-selectin is more sensitive, effective and specific than ${ }^{99 \mathrm{~m}} \mathrm{Tc}-\mathrm{HIG}$ scintigraphy to identify the active synovitis.

\section{Anti-CD20 antibody $\left({ }^{99 m}\right.$ Tc-rituximab)}

Rituximab (Rituxan ${ }^{\circledR}$ ) is a genetically engineered chimeric murine/human monoclonal antibody to CD20. Rituximab is produced by cell suspension culture technique, in a Chinese Hamster Ovary (CHO) mammalian expression system. Rituximab consists of IgG1 kappa immunoglobulin containing murine variable region sequences and human constant region sequences. CD-20 is a Bcell specific antigen expressed on the surface of $B$ lymphocytes throughout the differentiation from pre-B cell to the mature B-cell stages, but it is not found on haematopoietic stem cells, plasma cells or in normal tissues (Stashenko et al., 1980; Tedder et al., 1985). B-cells are involved in the production of auto-antibodies and rheumatoid factor (RF), $\mathrm{T}$ cell activation, pro-inflammatory cytokine production and therefore play an important role in the pathogenesis of different autoimmune diseases (Dorner et al., 2003). 
Rituximab binds to the CD20 antigen expressed on B lymphocytes with its Fab domain, and the Fc domain recruits immune effector functions to mediate B-cell lysis in vitro. In vivo rituximab induces depletion of both normal as well as malignant B cells (Reff et al., 1994). Rituximab's cytotoxicity is mediated by 3 different mechanisms, which are complement-mediated lysis (CDC), antibody-dependent cytotoxicity (ADCC) and direct disruption of signalling pathways and triggering of apoptosis. Different mechanisms predominate in the treatment of different diseases (Johnson et al., 2001; Olszewski et al., 2004).

Rituximab was radiolabelled with ${ }^{99 \mathrm{~m}} \mathrm{Tc}$ for imaging inflammation and infection (Stopar et al., 2006) by a photo-activation method developed by Stalteri et al. (1996). Besides labelling with ${ }^{99 \mathrm{~m}} \mathrm{Tc}$, rituximab was also labelled with ${ }^{90} \mathrm{Y}$ and ${ }^{131} \mathrm{I}$, but these radiopharmaceuticals are used in the cancer radioimmunotherapy mainly for B-cell lymphoma (Lindén et al., 2005).

Recently, this radiolabelled ritumixmab was used in mice as well as in breast cancer patients for sentinel lymphoscintigraphic examination. In this study, five balb/c mice and ten breast cancer patients underwent dynamic sentinel lymph node (SNL) mapping procedure using ${ }^{99 \mathrm{~m}} \mathrm{Tc}$ - rituximab. Results demonstrated that the ${ }^{99 \mathrm{~m}} \mathrm{Tc}$-labelled rituximab was found to be very reliable in showing the status of sentinel lymph nodes (SLN) both in mice and in breast cancer patients with a yield of 95\% (Wang et al., 2006).

\section{Anti-CD4 antibody}

CD4 is a membrane glycoprotein expressed on T lineage cells, including the majority of thymocytes and a subset of peripheral $\mathrm{T}$ cells and monocytes. The extracellular domains of $\mathrm{CD} 4$ bind to the conserved regions of MHC II molecules on antigen-presenting cells (APCs). $\mathrm{CD}^{+} \mathrm{T}$ cells constitute the helper subset which regulate $\mathrm{T}$ and $\mathrm{B}$ cell function during $\mathrm{T}$ cell dependent responses. A number of anti-CD4 monoclonal antibodies including murine and primatized have been available for the management of different autoimmune diseases. These monoclonal antibodies bind with high affinity to human CD4, induce CD4 receptor down regulation, and are potent inhibitor of $\mathrm{T}$ cell response.

Several studies have been performed in patients with different autoimmune diseases using antiCD4 monoclonal antibody which demonstrated its specificity for inflammation. A ${ }^{99 \mathrm{~m}} \mathrm{Tc}$-labelled CD4 specific antibody scintigraphic study was performed by Becker et al. (1990) in patients with active RA. In this study, the CD4 monoclonal antibody (MAX. 16H5) was labelled with ${ }^{99 \mathrm{~m}} \mathrm{Tc}$ by a direct method using 2-mercaptoethanol. Each patient received a sub-therapeutic dose of ${ }^{99 \mathrm{~m}} \mathrm{Tc}$ labelled CD4 specific antibody and they were examined at $1.5 \mathrm{~h}, 4 \mathrm{~h}$ and $24 \mathrm{~h}$ post-injection. This study demonstrated that the ${ }^{99 \mathrm{~m}}$ Tc-labelled CD4 specific antibody can specifically detect the diseased joints in the patients with active RA.

In another study to detect the specific binding of anti-CD4 $\mathrm{mAb}$ to its target molecule performed by Kinne et al. (1993), a direct comparison between radiolabelled specific anti-CD4 $\mathrm{mAb}$ and nonspecific human immunoglobulin for imaging inflamed joints in RA patients was performed. Patients with active or severe RA were intravenously injected with a sub-therapeutic dose of ${ }^{99 \mathrm{~m}} \mathrm{Tc}$ - labelled murine anti-human CD4 mAb (MAX.16H5) or ${ }^{99 \mathrm{~m}}$ Tc- labelled HIG. Whole body and joint specific scintigraphic images were acquired at $1 \mathrm{~h}, 4 \mathrm{~h}$ and $24 \mathrm{~h}$. In this study, the authors concluded that the ${ }^{99 \mathrm{~m}} \mathrm{Tc}-$ anti-CD $4 \mathrm{mAb}$ allows more specific detection of inflammatory infiltrates which are rich in CD4-positive cells.

\section{Anti-CD3 antibody ( ${ }^{99 \mathrm{~m}} \mathrm{Tc}$-muromonab-CD3)}

Muromonab-CD3 (Orthoclone $\mathrm{OKT}^{\circledR} 3$ ) is a murine monoclonal antibody to the $\mathrm{CD} 3$ antigen of human $\mathrm{T}$ cells. The antibody is a biochemically purified $\mathrm{IgG}_{2 \mathrm{a}}$ immunoglobulin. Muromonab-CD3 reacts with and blocks the function of $\mathrm{CD} 3$ in the membrane of human $\mathrm{T}$ cells that has been associated in vitro with the antigen recognition structure of $\mathrm{T}$ cells and is essential for signal transduction. Binding of muromonab-CD3 to $\mathrm{T}$ lymphocytes result in early activation of $\mathrm{T}$ cells, this leads to cytokine release, followed by blocking of $\mathrm{T}$ cell functions. In vivo, muromonab$\mathrm{CD} 3$ reacts with most peripheral blood $\mathrm{T}$ cells and $\mathrm{T}$ cells in body tissues, but has not been found to react with other haematopoietic elements or other tissues of the body.

Recently, in a study performed by Martins et al. (2004), OKT3 was labelled with technetium-99m according to the technique developed by Martins and Gutfilen (2002). The use of ${ }^{99 \mathrm{~m}} \mathrm{Tc}-\mathrm{OKT} 3$ scintigraphy in diagnosis of acute rejection in renal transplants was subsequently evaluated. Among 22 patients that underwent renal transplantation, they reported an increased ${ }^{99 \mathrm{~m}}$ Tc-OKT3 kidney uptake 
with time in 3 patients with rejecting allografts, differentiating them from those without this abnormality. Furthermore, these findings agreed with those of biopsies. In this study, the authors concluded that the ${ }^{99 \mathrm{~m}} \mathrm{Tc}-\mathrm{OKT} 3$ scans may be used as a diagnostic method to identify kidney allograft rejection, possibly allowing a balance between adequate immunosuppression to prevent rejection of an allograft and excessive immunosuppression.

We have recently radiolabelled with $99 \mathrm{mTc}$ a different MoAb anti-human CD3, Visilizumab (Nuvion ${ }^{\circledR}$ ) and demonstrated its capacity to bind in vitro and in vivo to human T-lymphocytes (unpublished data). Indeed, this antibody is very promising not only for in vivo imaging of lymphocytes but also to provide a rationale for therapy with Nuvion ${ }^{\circledR}$ and to early follow-up the efficacy of therapy.

\section{Anti-DR antibody}

The HLA-DR antigens play important roles in the cellular interaction involved in immune response. The HLA-DR is normally expressed on B lymphocytes, activated $\mathrm{T}$ lymphocytes, macrophages, monocytes, dendritic cells, activated NK cells and progenitor haemopoietic cells. During the resting state of T lymphocytes DR is not expressed and is therefore very specific for $\mathrm{T}$ cell activation. It is well known that this activation antigen is normally expressed on tissue infiltrating lymphocytes in inflamed tissues, in a high percentage of cells and for a longer time span compared to other activation markers, such as CD25 (IL2 receptor). It is therefore, a stable and reliable marker for detection of $\mathrm{T}$ cell mediated inflammation. Isobe et al. (1992), described that other tissues, such as vessel endothelium, may express DR following the release of local inflammatory molecules. Using ${ }^{111}$ In-labelled antiDR monoclonal antibody, Isobe (1993) found the expression of MHC class II antigens in a rat model of heart rejection and in mouse kidney allograft rejection. Indeed the scintigraphy revealed the presence of DR molecules on both the graft endothelium and the infiltrating mononuclear cells.

We have recently, radiolabelled labelled anti-DR monoclonal antibody (1D09C3) with technetium$99 \mathrm{~m}$. Using the 2-ME method, a high labelling efficiency of $90 \%$ and specific activity of 110.2 $\mathrm{mCi} / \mathrm{mg}$ was obtained (unpublished data). 1D09C3 is a fully humanised $\mathrm{IgG}_{4}$ monoclonal antibody and does not induce Fc-portion-mediated side effects, like chimeric antibodies do (Billing and Chatterjee, 1983; Jonker et al., 1988). Studies demonstrated that 1D09C3 has in vivo as well as in vitro tumoricidal activity and it can act selectively on tumor-transformed and activated cells via a non-apoptotic mechanism (Nagy et al., 2002). The ${ }^{99 \mathrm{~m}}$ Tc- labelled Anti-DR monoclonal antibody can provide a useful tool for imaging of inflammation and several cancer types, mainly leukaemia and lymphoma cells.

Furthermore, Rimsza et al. (2007) demonstrated that the HLA-DR can be used as a prognostic marker in the patients with diffuse large B-cell lymphoma (DLBCL). They demonstrated that the HLA-DR protein status predicts the survival in patients with DLBCL treated with the MACOP-B chemotherapy regimen. These findings have suggested the use of anti-DR monoclonal antibodies for diagnostic and therapeutic purposes.

\section{Radiolabelled Cytokines}

Cytokines are the soluble proteins produced by different types of activated cells (mainly $\mathrm{T}$ cells and macrophages). Cytokines play a prominent role in the regulation of cell function, homing, motility and metastasis through interaction with specific cell surface receptors expressed on a known cell population. Cytokine receptors, usually of high affinity, are normally present at low levels on non-activated cells, but expression is up regulated during the cell activation and therefore these receptors on the affected tissue are suitable targets for the detection of infection/inflammation.

\section{Interleukin 2}

Presently, Interleukin 2 (IL-2) is among the best approaches for the imaging of chronic inflammation, although it binds both to $\mathrm{Th}_{1}$ and $\mathrm{Th}_{2}$ cells. IL-2 is a single chain glycoprotein of 133 amino acids that is mainly produced by activated $\mathrm{T}$ cells. IL-2 interacts with a specific receptor expressed by activated $\mathrm{T}$ lymphocytes and plays a prominent role in regulating the immune mediated response through long term $\mathrm{T}$ cell proliferation and also promotes the proliferation of macrophages, B cells and NK cells (Smith et al., 1988). In inflammatory conditions, infiltrating cells in the inflamed tissue express the high affinity IL-2 receptors which are targeted by the radiolabelled IL-2. Initially, interleukin 2 was labelled with ${ }^{35} \mathrm{~S},{ }^{125} \mathrm{I}$ and ${ }^{131} \mathrm{I}$ for in-vitro studies and in-vivo biodistribution in animal models 
(Koths et al., 1985; Robb et al., 1985; Gennuso et al., 1989). After that IL-2 was radiolabelled with ${ }^{123} \mathrm{I}$ and ${ }^{{ }^{99 m} \mathrm{Tc}}$ for the imaging of chronic inflammation, its application in the patients with different disorders including inflammatory bowel diseases, autoimmune thyroid diseases, insulin dependent diabetes and melanoma has been investigated.

In a study in the patients with active Crohn's disease, ${ }^{123}$ I-IL2 was able to detect the presence of activated $\mathrm{T}$ lymphocytes in inflamed tissue. Exvivo autoradiographic examinations demonstrated the specific binding of ${ }^{123}$ I-IL2 to activated lymphocytes in the inflamed gut mucosa (Signore et al., 1999a). In another study in the patients with coeliac disease, a positive correlation was observed between the uptake of ${ }^{123} \mathrm{I}$-IL-2 measured by gamma camera and the number of histologically determined IL-2 receptor-positive cells in the inflamed jejunal mucosa (Signore et al., 1999b). Similarly, ${ }^{99 \mathrm{~m}}$ Tc-labelled IL-2 also showed specific accumulation in the inflamed tissue in several diseases such as insulin dependent diabetes (Signore et al., 1996) and melanoma (Barone et al., 1998). These studies suggest that the radiolabelled IL-2 could be used as a potential radiopharmaceutical for scintigraphic imaging of chronic inflammation.

\section{${ }^{67}$ GA-CITRATE}

${ }^{67} \mathrm{Ga}$-citrate as a radiopharmaceutical for imaging infection and inflammation was discovered in 1971 (Lavender et al., 1971). As an analogue of iron, ${ }^{67} \mathrm{Ga}$-citrate binds in ionic form to circulating transferrin. Transferrin-bound ${ }^{67} \mathrm{Ga}$ uses transferrin receptors $(\mathrm{CD} 71)$ to access the cell and then remains stably trapped within the cells (except RBCs) (Chianelli et al., 1997). During acute inflammation condition, ${ }^{67} \mathrm{Ga}$-citrate is extravasated at the site of inflammation due to the locally enhanced vascular permeability. The extravasated radiopharmaceutical binds with high affinity to lactoferrin excreted by leukocytes or to siderophores, produced by microorganisms growing in a low-iron environment. Approximately, 25\% of the total injected dose is excreted through urinary system and rest is retained in the bone, bone marrow, liver and soft tissues (Hoffer, 1980). However, this radiopharmaceutical has long physical half-life (78 hours) and high energy gamma radiations, which are unfavourable characteristics for $\gamma$-camera imaging and cause high radiation absorbed dose in the patients.

The use of this radiopharmaceutical is mainly restricted to chronic osteomyelitis, lung infection and fever of unknown origin (FUO), especially in immunocompromised patients.

\section{${ }^{99}$ Tc-JOO1X}

The non-pyrogenic acylated polygalactoside, J001X, is isolated from the membrane proteoglycans of a non-pathogenic strain of Klebsiella pneumoniae. JOO1X selectively binds to $\mathrm{CD} 11 \mathrm{~b}$, the complement receptor 3 expressed on monocytes, NK cells and macrophages, as well as to $\mathrm{CD} 14$, the lipopolysaccharide receptor expressed on macrophages and monocytes (Chianelli et al., 2006; Hmama et al., 1992). It preferably binds to macrophages, mainly in their activated state (Bois de et al., 1995). As inflammatory foci are characterised by the recruitment of macrophages, they could in principle be imaged with ${ }^{99 \mathrm{~m}} \mathrm{Tc}-\mathrm{J} 001 \mathrm{X}$. Radiolabelled J001X has been used in several experimental animal studies including alveolitis and inflammatory lymph nodes in chronic berilliosis in baboons (Diot et al., 1992), inflammatory lesions in pigs (Perin et al., 1993) and rabbit arthritis model (Goupille et al., 1994; Miot-Noirault et al., 1996).

\section{${ }^{18}$ F-FDG $\left({ }^{18}\right.$ F- fluorodeoxyglucose $)$}

${ }^{18} \mathrm{~F}$ is a positron emitter with a physical half-life of 1 hour and $50 \mathrm{~min}$. The FDG (2'-deoxy-2'-fluroD-glucose) accumulation in activated lymphocytes, monocytes and granulocytes is based on the fact that these cells use glucose as an energy source only after activation during the metabolic burst. Transport of FDG across the cellular membrane is mediated by glucose transporter proteins. Intracellular FDG is subsequently phosphorylated to $\left[{ }^{18} \mathrm{~F}\right] \mathrm{FDG}-6$ phosphate by the hexokinase enzyme and phosphorylated radiopharmaceutical remains trapped inside the cell in contrast to phosphorylated glucose that enters in the glycolysis.

Several PET (positron emission tomography) studies have been performed using ${ }^{18} \mathrm{~F}$-FDG in patients with different inflammatory disorders such as vasculitis, Crohn's disease, sarcoidosis and rheumatoid arthritis, in addition to infection such as osteomyelitis, spondylodicitis and prosthetic joint infection. Recently, Beckers et al. (2006) 
performed a study using ${ }^{18}$ F-FDG PET on 16 patients with active RA. They found PET was positive in $69 \%$ of the knees, while magnetic resonance imaging (MRI) and ultrasonography (US) were positive in $69 \%$ and $75 \%$, respectively. A study demonstrated that visual identification of RA knee synovitis by ${ }^{18} \mathrm{~F}$-FDG PET is related to its visual identification with MRI and US. The standardised uptake values also correlated with serum CRP (C-reactive protein) and MMP-3 (matrix metalloproteinase-3) levels.

Studies in the patients with spondylodiscitis proved FDG PET to be superior to MRI, ${ }^{67} \mathrm{Ga}-$ citrate scintigraphy and three phase bone scan for visualization (Gratz et al., 2002; Schmitz et al., 2001). Moreover, FDG PET is also able to differentiate between mild infection and degenerative changes (Stumpe et al., 2002). These studies conclude that FDG PET is highly sensitive tool to detect suspected osteomyelitis of the central skeleton, spondylodiscitis or chronic low-grade infections of the peripheral skeleton.

Although FDG PET is a useful tool for detection of inflammation and infection in many disorders, it has some limitations in others. FDG PET does not seem suitable for detection of other types of inflammation such as the insulitis in the pancreas of diabetic patients. Although ex-vivo studies in NOD mice demonstrated enhanced FDG uptake in islets of Langerhans that were affected by insulitis, the relatively small difference between diseased and healthy islets and the small size of the islets combined with the limited resolution of the PET camera will most likely prevent successful application in patients (Kalliokoski et al., 2005). Besides FDG, no validated PET tracers for imaging of peripheral inflammation are available and thus more sensitive tracers for PET imaging of insulitis are urgently awaited.

The brain is another organ, in which application of FDG PET for detection of inflammation or infection is limited. Since the brain uses glucose as its source of energy, basal FDG uptake in healthy brain is high and consequently increased FDG uptake as a result of inflammation can be hard to detect. Moreover, changes in FDG uptake are not specific for inflammation, but can also be induced by other physiological causes, like activation of a specific brain region by an external stimulus or a specific task (Grafton, 2000). In addition, the inflammation-induced increase in FDG uptake can be obscured by neurodegeneration, which leads to a reduction in glucose consumption. Consequently, neurodegenerative diseases that are associated with chronic inflammation, such as Alzheimer's disease and Parkinson's disease, show characteristic patterns of glucose hypometabolism on PET scans due to destruction of brain tissue (Herholz, 2003), whereas acute encephalitic disorders usually exhibit distinct areas of glucose hypermetabolism, sometimes accompanied with hypometabolism in atrophic brain regions (Lee et al., 2004).

\section{Other PET radiopharmaceuticals for neuroinflammation}

Because of the aforementioned limitations of detection of neuroinflammation by FDG PET and the limited brain penetration of large proteins like radiolabelled cytokines and antibodies, radiopharmaceuticals targeting specific processes in neuroinflammation, like activation of microglial cells, have been developed. Microglia is the macrophage equivalents of the central nervous system. Activation of microglia by an inflammatory stimulus is accompanied by an increase in density of their mitochondria and a strong upregulation of the expression of peripheral benzodiazepine receptors (PBR) on the outer mitochondrial membrane. Not only microglia cells, but also astrocytes show increased PBR expression in response to brain inflammation. Thus, the PBR is an attractive target for imaging of neuroinflammation.

\section{$\left[{ }^{11} \mathrm{C}\right]$ PK11195}

Currently, $\left[{ }^{11} \mathrm{C}\right] \mathrm{PK} 11195$ is the best validated PET tracer for imaging PBR expression as a measure of inflammation-induced microglia activation. $\left[{ }^{11} \mathrm{C}\right]$ PK11195 PET has been successfully applied in a variety of neurological disorders. In patients with viral encephalitis, like for example HSV encephalitis (Cagnin et al., 2001a), Rasmussen's encephalitis (Banati et al., 1999) and AIDS (Hammoud et al., 2005), $\left[{ }^{11} \mathrm{C}\right]$ PK11195 PET could clearly identify brain areas with activated microglia. In fact, increased uptake was also detected in brain areas that appeared normal on MRI at the time of investigation, but which developed marked atrophy several months later. $\left[{ }^{11} \mathrm{C}\right]$ PK11195 PET could also be applied successfully in dementia. In a PET study on patients with Alzheimer's disease, including patients with mild disease, increased $\left[{ }^{11} \mathrm{C}\right]$ PK11195 binding was observed in affected brain regions (Cagnin et al., 2001b). Brain regions 
with high $\left[{ }^{11} \mathrm{C}\right] \mathrm{PK} 11195$ uptake exhibited signs of atrophy on follow-up MRI and FDG PET scans. $\left[{ }^{11} \mathrm{C}\right] \mathrm{PK} 11195$ PET could also demonstrate microglia activation in other forms of dementia, like frontotemporal dementia (Cagnin et al., 2004). In drug-naive patients with early Parkinson's disease, $\left[{ }^{11} \mathrm{C}\right]$ PK11195 PET revealed enhanced microglia activation in midbrain, as compared to healthy controls (Ouchi et al., 2005). The uptake of $\left[{ }^{11} \mathrm{C}\right] \mathrm{PK} 11195$ in midbrain positively correlated with the severity of motor deficits. An inverse correlation was found between midbrain $\left[{ }^{11} \mathrm{C}\right] \mathrm{PK} 11195$ uptake and nerve terminal loss in striatum. In patients suffering from multiple sclerosis, enhanced $\left[{ }^{11} \mathrm{C}\right] \mathrm{PK} 11195$ uptake seems to correlate with new lesions, whereas old lesions show little tracer uptake (Banati et al., 2000). Focal $\left[{ }^{11} \mathrm{C}\right] \mathrm{PK} 11195$ binding in structures that appeared normal by MRI and asymmetric increased tracer uptake in thalamus and brain stem were also observed. T2-weighted MRI lesions with elevated $\left[{ }^{11} \mathrm{C}\right] \mathrm{PK} 11195$ binding showed an increase in tracer uptake during relapse (Debruyne et al., 2003). In stroke patients, areas with enhanced $\left[{ }^{11} \mathrm{C}\right] \mathrm{PK} 11195$ uptake overlap areas with abnormalities on MRI, but tend to be bigger. Several months after the stroke, the area of $\left[{ }^{11} \mathrm{C}\right] \mathrm{PK} 11195$ binding has extended from the primary infarction site into connected areas in the same hemisphere and the contralateral thalamus, whereas atrophy has developed in the areas that originally exhibited the highest tracer uptake (Gerhard et al., 2005).

As follows from the above, $\left[{ }^{11} \mathrm{C}\right] \mathrm{PK} 11195$ PET can reveal early inflammatory responses, before abnormalities are visible by MRI. Increased PK11195 binding in areas that appear normal on MRI, were shown to develop atrophy afterwards, suggesting that microglial activation precedes neurodegeneration and thus could be used as an early predictor of disease progression.

\section{Novel tracer for the PBR}

Despite the successful applications reported so far, $\left[{ }^{11} \mathrm{C}\right] \mathrm{PK} 11195$ is not an ideal tracer. Signal to noise ratios can be rather low, because of the high lipophilicity, high plasma protein binding and relatively poor brain penetration of the PET tracer. Therefore, various novel PET tracers for the PBR with improved properties are currently being developed. Amongst these novel tracers $\left[{ }^{11} \mathrm{C}\right] \mathrm{DPA} 713, \quad\left[{ }^{11} \mathrm{C}\right] \mathrm{DAA} 1106 \quad$ and $\left[{ }^{18}\right.$ F]FEDAA1106 appear to be most promising. $\left[{ }^{11} \mathrm{C}\right] \mathrm{DPA} 713$ is still in the preclinical phase of development. In rats with unilateral lesions induced by intra-striatal injection of AMPA, $\left[{ }^{11} \mathrm{C}\right] \mathrm{DPA} 713$ displayed a higher lesion-tobackground contrast than $\left[{ }^{11} \mathrm{C}\right] \mathrm{PK} 11195$, which was mainly due to lower nonspecific binding of $\left[{ }^{11} \mathrm{C}\right] \mathrm{DPA} 713$ in healthy brain (Boutin et al., 2007). However, further evaluation in humans is still required before the value of this tracer can be assessed. $\left[{ }^{11} \mathrm{C}\right] \mathrm{DAA} 1106$ and its $\left[{ }^{18} \mathrm{~F}\right]$ fluoroethyl derivative $\left[{ }^{18} \mathrm{~F}\right]$ FEDAA1106 have a much higher affinity for the PBR than $\left[{ }^{11} \mathrm{C}\right] \mathrm{PK} 11195$ and consequently exhibit 4-6 fold higher uptake in PBR-rich regions in monkey brain (Maeda et al., 2004; Zhang et al., 2004). Like $\left[{ }^{11} \mathrm{C}\right] \mathrm{DPA} 713$, $\left[{ }^{11} \mathrm{C}\right] \mathrm{DAA} 1106$ demonstrated increased tracer uptake in lesioned brain areas of rats that were unilaterally injected with kainic acid in the hippocampus. $\left[{ }^{11} \mathrm{C}\right]$ DAA1106, $\left[{ }^{18} \mathrm{~F}\right]$ FEDAA1106 have already been evaluated in healthy human volunteers. For both tracers quantitative analysis of receptor binding is feasible, but long scan times are required, because of the low kinetics of tracer dissociation from the receptor (Fujimura et al., 2006; Ikoma et al., 2007). None of the novel tracers have been used in patients to measure neuroinflammation yet.

\section{RESUMO}

Nas últimas décadas, foram propostos vários radiofármacos para obtenção de imagens de sítios de inflamação, diferindo em suas especificidades e mecanismos de captação quando comparados aos tradicionais agentes utilizados para essa finalidade. Citocinas radiomarcadas representam uma ferramenta confiável para o diagnóstico pré-clinico precoce de processos inflamatórios crônicos, anterior às alterações anatômicas e funcionais, em tecidos afetados. Além disso, a introdução de anticorpos monoclonais radiomarcados e técnicas sofisticadas, como PET/CT, tornaram a obtenção de imagens de focos de inflamação altamente específica e apurada. Nesta revisão, diferentes abordagens com radiofármacos já bem estabelecidos e com outros em nível experimental para a obtenção de imagens de sítios de inflamação crônica são discutidas. 


\section{REFERENCES}

Abrams, M. J., Juweid, M., tenKate, C. I., Schwartz, D. A., Hauser, M. M., Gaul, F. E., Fuccello, A. J., Rubin, R. H., Strauss, H. W., Fischman, A. J. (1990), Technetium-99m-human polyclonal IgG radiolabelled via the hydrazino nicotinamide derivative for imaging focal sites of infection in rats. J. Nucl. Med., 31, 2022-2028.

Annovazzi A., D’Alessandria C., Caprilli R., Viscido A., Corsetti F., Parisella M. G. (2002), Radiolabelling of a monoclonal anti-TNF- $\alpha$ antibody with $99 \mathrm{mTc}$ : in vitro studies. $Q$. J. Nucl. Med. Mol. Imaging, 46 (Suppl)1, 27.

Banati, R. B., Goerres, G. W., Myers, R., Gunn, R. N., Turkheimer, F. E., Kreutzberg, G. W., Brooks, D. J., Jones, T., Duncan, J. S. (1999), [11C](R)-PK11195 positron emission tomography imaging of activated microglia in vivo in Rasmussen's encephalitis. Neurology, 53, 2199-2203.

Banati, R. B., Newcombe, J., Gunn, R. N., Cagnin, A., Turkheimer, F., Heppner, F., Price, G., Wegner, F., Giovannoni, G., Miller, D. H., Perkin, G. D., Smith, T., Hewson, A. K., Bydder, G., Kreutzberg, G. W., Jones, T., Cuzner, M. L., Myers, R. (2000), The peripheral benzodiazepine binding site in the brain in multiple sclerosis: quantitative in vivo imaging of microglia as a measure of disease activity. Brain, 123, 2321-2337.

Barone, R., Chianelli, M., Procaccini, E., Chianelli, M., Bottoni, U., Panetta, C., Innocenzi, D., Calvieri, S., Signore, A. (1998), 99mTc-IL-2 scintigraphy in patients with cutaneous melanoma: detection of lymphocytic infiltration. (abstract) Eur. J. Nucl. Med., 25, 896.

Barrera, P., Oyen, W. J. G., Boerman, O. C., van Riel, P. L. C. M. (2003), Scientigraphic detection of tumour necrosis factor in patients with rheumatoid arthritis. Ann. Rheum. Dis., 62, 825-828.

Beckers, C., Jeukens, X., Ribbens, C., André, B., Marcelis, S., Leclercq, P., Kaiser, M. J., Foidart, J., Hustinx, R., Malaise, M. G. (2006), ${ }^{18}$ F-FDG PET imaging of rheumatoid knee synovitis correlates with dynamic magnetic resonance and sonographic assessment as well as with the serum level of metalloproteinase-3. Eur. J. Nucl. Med., 33, 275-280.

Becker, W., Emmrich, F., Horneff, G., Burmester, G., Seiler, F., Schwarz, A., Kalden, J., Wolf, F. (1990), Imaging rheumatoid arthritis specifically with technetium 99m CD4-specific (T-helper lymphocytes) antibodies. Eur. J. Nucl. Med., 17, 156159.

Benitez, A., Roca, M., Martin-Comin, J. (2006), Labeling of antibiotics for infection diagnosis. Q. J. Nucl. Med. Mol. Imaging, 50, 147-152.
Bernardo-Filho, M., Santos-Filho, S., Moura, E., Maiworm, A., Orlando, M., Penas, M., Cardoso, V., Bernardo, L., Brito, L. (2005), Drug interaction with radiopharmceuticals: a review. Braz. Arch. Biol. Technol., 48, 13-27.

Bevilacqua, M. P., Stengelin, S., Gimbrone, M. A., Seed, B. (1989), Endothelial leucocyte adhesion molecule-1: an inducible receptor for neutrophils related to complement proteins and lectins. Science, 243, 1160-1165.

Bevilacqua, M. P. (1993), Endothelial-leukocytes adhesion molecules. Ann. Rev. Immunol., 11, 767804.

Bevilacqua, M. P., Nelson, R. M. (1993), Selectins. J. Clin. Invest., 91, 379-387.

Bhushan, M., Bleiker, T. O., Ballsdon, A. E., Allen, M. H., Sopwith, M., Robinson, M. K., Clarke, C., Weller, R. P. J. B., Graham-Brown, R. A. C., Keefe, M., Barker, J. N. W. N., Griffiths, C. E. M. (2002), Anti-E-selectin is ineffective in the treatment of psoriasis: a randomized trial. Br. J. Dermatol., 146, 824-831.

Billing, R.., Chatterjee, S. (1983), Prolongation of skin allograft survival in monkeys treated with anti-Ia and anti-blast/monocyte monoclonal antibodies. Transplant. Proc., 15, 649-650.

Bleeker-Rovers, C. P., Boerman, O. C., Rennen, H. J. J. M., Corstens, F. H. M., Oyen, W. J. G. (2004), Radiolabeled Compounds in Diagnosis of Infectious and Inflammatory Disease. Curr. Pharm. Design, 10, 2935-2950.

Bois de, M. H. W., Pauwels, E. K. J., Breedveld, F. C. (1995), New agents for scintigraphy in rheumatoid arthritis. Eur. J. Nucl. Med., 22, 1339-1346.

Boutin, H., Chauveau, F., Thominiaux, C., Gregoire, M. C., James, M. L., Trebossen, R., Hantraye, P., Dolle, F., Tavitian, B., Kassiou, M. (2007), 11C-DPA-713: a novel peripheral benzodiazepine receptor PET ligand for in vivo imaging of neuroinflammation. J. Nucl. Med., 48, 573-581.

Buscombe, J. R. (2006), Future of infection imaging. $Q$. J. Nucl. Med. Mol. Imaging, 50, 99-103.

Cagnin, A., Myers, R., Gunn, R. N., Lawrence, A. D., Stevens, T., Kreutzberg, G. W., Jones, T., Banati, R. B. (2001a), In vivo visualization of activated glia by [11C] (R)-PK11195-PET following herpes encephalitis reveals projected neuronal damage beyond the primary focal lesion. Brain, 124, 20142027.

Cagnin, A., Brooks, D. J., Kennedy, A. M., Gunn, R. N., Myers, R., Turkheimer, F. E., Jones, T., Banati, R. B. (2001b), In-vivo measurement of activated microglia in dementia. Lancet, 358, 461-467.

Cagnin, A., Rossor, M., Sampson, E.L., Mackinnon, T., Banati, R. B. (2004) In vivo detection of microglial activation in frontotemporal dementia. Ann. Neurol., 56, 894-897. 
Chapman, P. T., Jamar, F., Keelan, E. T., Peters, A. M., Haskard, D. O. (1996), Use of monoclonal antibody against E-selectin for imaging endothelial activation in rheumatoid arthritis. Arthritis Rheum., 39, 13711375.

Chianelli, M., D’Alessandria, C., Conti, F., Priori, R., Valesini, G., Annovazzi, A., Signore, A. (2006), New radiopharmaceuticals for imaging rheumatoid arthritis. Q. J. Nucl. Med. Mol. Imaging, 50, 217-225.

Cindas, A., Gokce-Kutsal, Y., Kirth, P. O., Caner, B. (2001), Scintigraphic evaluation of synovial inflammation in rheumatoid arthritis with ${ }^{99 m}$ technetium-labelled human polyclonal immunoglobulin G. Rheumatol. Int., 20, 71-77.

Conti, F., Priori, R., Chimenti, M.S., Coari, G., Annovazzi, A., Valesini, G., Signore, A. (2005), Successful treatment with intraarticular infliximab for resistant knee monarthritis in a patient with spondylarthropathy a role for scintigraphy with ${ }^{99 \mathrm{~m}}$ Tc-infliximab. Arth. Rheum., 52, 1224-1226.

Corstens, F. H. S., Oyen, W. J. G., Becker, W. S. (1993), Radioimmunoconjugates in the detection of infection and inflammtion. Semin. Nucl. Med., 23, 148-164.

D’Alessandria, C., Malviya, G., Viscido, A., Aratari, A., Maccioni, F., Amato, A., Scopinaro, F., Caprilli, R., Signore, A. (2007), Use of a 99m-Technetium labelled anti-TNF $\alpha$ monoclonal antibody in Crohn's Disease: in vitro and in vivo studies. Q. J. Nucl. Med. Mol. Imaging, 51, 1-9.

Debruyne, J. C., Versijpt, J., Van Laere, K. J., De Vos, F., Keppens, J., Strijckmans, K., Achten, E., Slegers, G., Dierckx, R. A., Korf, J., De Reuck, J. L. (2003), PET visualization of microglia in multiple sclerosis patients using [11C]PK11195. Eur. J. Neurol., 10, 257-264.

Diot, P., Le Pape, A., Nolibe, D., Normier, G., Binz, H., Revillard, J. P., Lasfargues, G., Lavandier, M., Lemarie, E. (1992), Scientigraphy with J001X, a Klebsiella membrane glycolipid, for the early diagnosis of chronic berilliosis: Results from an experimental model. Br. J. Int. Med., 49, 359-364.

Dorner, T., Rumester, G. (2003), The role of B-cells in rheumatoid arthritis: mechanisms and therapeutic targets. Curr. Op. Rheum., 15, 246-252.

Fujimura, Y., Ikoma, Y., Yasuno, F., Suhara, T., Ota, M., Matsumoto, R., Nozaki, S., Takano, A., Kosaka, J., Zhang, M.R., Nakao, R., Suzuki, K., Kato, N., Ito, H. (2006), Quantitative analyses of 18F-FEDAA1106 binding to peripheral benzodiazepine receptors in living human brain. J. Nucl. Med., 47, 43-50.

Gennuso, R., Spigelman, M.K., Vallabhajosula, S., Moore, F., Zappulla, R., Nieves, J., Strauchen, J. A., Paciucci, A., Malis, L. I., Goldsmith, S. J., Holland, J. F. (1989) Systemic biodistribution of radioiodinated interleukin-2 in the rat. J. Biol. Resp. Mod., 8, 375384.
Gerhard, A., Schwarz, J., Myers, R., Wise, R., Banati, R. B. (2005), Evolution of microglial activation in patients after ischemic stroke: a [11C](R)-PK11195 PET study. Neuroimage, 24, 591-595.

Grafton, S. T. (2000), PET: activation of cerebral blood flow and glucose metabolism. Adv. Neurol., 83, 87103.

Gratz, S., Dörner, J., Fischer, U., Behr, T. M., Béhé, M., Altenvoerde, G., Meller, J., Grabbe, E., Becker, W. (2002), 18F-FDG hybrid PET in patients with suspected spondylitis. Eur. J. Nucl. Med. Mo.l Imaging, 29, 516-524.

Goupille, P., Valat, J. P., Le Pape, A. (1994), Imaging of synovitis in rheumatoid arthritis with radionuclide tracer. J. Rheumatol., 21, 1975-1976.

Hammoud, D. A., Endres, C. J., Chander, A. R., Guilarte, T. R., Wong, D. F., Sacktor, N. C., McArthur, J. C., Pomper, M. G. (2005), Imaging glial cell activation with [11C]-R-PK11195 in patients with AIDS. J. Neurovirol., 11, 346-355.

Herholz, K. (2003), PET studies in dementia. Ann. Nucl. Med., 17, 79-89.

Hmama, Z., Normier, G., Kouassi, E., Flacher, M., Binz, H., Revillard, J. P. (1992), Binding of a membrane proteoglycan from klebsiella pneumonia and its derivatives to human leukocytes. Immunobiology, 186, 183-198.

Hoffer, P. (1980), Gallium: mechanism. J. Nucl. Med., 21, 282-285.

Ikoma, Y., Yasuno, F., Ito, H., Suhara, T., Ota, M., Toyama, H., Fujimura, Y., Takano, A., Maeda, J., Zhang, M. R., Nakao, R., Suzuki, K. (2007), Quantitative analysis for estimating binding potential of the peripheral benzodiazepine receptor with [11C]DAA1106. J. Cerebral Blood Flow Metabol., 27, 173-184.

Isobe, M. (1993), Scintigraphic imaging of MHC class II antigen induction in mouse kidney allografts: a new approach to non-invasive detection of early rejection. Transpl Int., 6, 263-269.

Isobe, M., Narula, J., Southern, J. F., Strauss, H. W., Khaw, B. A., Haber, E. (1992), Imaging the rejecting heart. In vivo detection of major histocompatibility complex class II antigen induction. Circulation, 85, 738-746.

Jamar, F., Chapman, P. T., Manicourt, D-H., Glass, D. M., Haskard, D. O., Peters, A. M. (1997), A comparison between ${ }^{111}$ In-anti-E-selectin $\mathrm{mAb}$ and ${ }^{99} \mathrm{Tc}^{\mathrm{m}}$-labelled human non-specific immunoglobulin in radionuclide imaging of rheumatoid arthritis. Brit. J. Radiol., 70, 473-481.

Jamar, F., Chapman, P. T., Harrison, A. A., Binns, R. M., Haskard, D. O., Peters, A. M. (1995), Inflammatory arthritis: imaging of endothelial cell activation with an indium-111-labelled $F\left(a^{\prime}\right.$ ')2 fragment of anti-E-selectin monoclonal antibody. Radiology, 194, 843-850. 
Johnson, P. W., Glennie, M. J. (2001), Rituximab: mechanisms and applications. Br. J. Cancer, 85, 1619-1623.

Jonker, M., Nooij, F. J. M., den Butter, G., van Lambalgen, R., Fuccello, A. J. (1988), Side effects and immunogenicity of murine lymphocyte-specific monoclonal antibodies in subhuman primates. Transplantation, 45, 677-682.

Kalliokoski, T., Simell, O., Haarparanta, M., Viljanen, T., Solin, O., Knuuti, J., Nuutila, P. (2005), An autoradiographic study of [18F]FDG uptake to islets of Langerhans in NOD mouse. Diabetes Res. Clin. Practice, 70, 217-224.

Keelan, E. T. M., Harrison, A. A., Chapman, P. T., Binns, R. M., Peters, A. M., Haskard, D. 0. (1994), Imaging vascular endothelial activation: an approach using radiolabeled monoclonal antibodies against the endothelial cell adhesion molecule E-selectin. $J$. Nucl. Med., 35, 276-281.

Kinne, R. W., Becker, W., Schwab, J., Horneff, G., Schwarz, A., Kalden, J. R., Emmrich, F., Burmester, G. R., Wolf, F. (1993), Comparison of 99Tcmlabelled specific murine anti-CD4 monoclonal antibodies and nonspecific human immunoglobulin for imaging inflamed joints in rheumatoid arthritis. Nucl. Med. Commun., 14, 667-675.

Knight, D. M., Trinh, H., Le, J., Siegel, S., Shealy, D., McDonough, M., Scallon, B., Moore, M. A., Vilcek, J., Daddona, P., Ghrayeb, J. (1993), Construction and initial characterization of a mouse-human chimeric anti-TNF antibody. Mol. Immunol., 30, 1443-1453.

Koths, K., Halenbech, R. (1985), Pharmacokinetic studies on 35S-labelled recombinant interleukin-2 in mice. In: Cellular and Molecular Biology of Lymphokines. Academic Press Inc., pp. 779-783.

Lavender, J. P., Lowe, J., Barker, J. R., Burn, J. I., Chaudhri, M. A. (1971), Gallium 67 citrate scanning in neoplastic and inflammatory lesions. Br. J. Radiol., 44, 361-366.

Lee, B. Y., Newberg, A. B., Liebeskind, D. S., Kung, J., Alavi, A. (2004), FDG-PET findings in patients with suspected encephalitis. Clin. Nucl. Med., 29, 620-625.

Lindén, O., Kurkus, J., Garkavij, M., Cavallin-Ståhl, E., Ljungberg, M., Nilsson, R., Ohlsson, T., Sandberg, B., Strand, S. E., Tennvall, J. (2005), A Novel Platform for Radioimmunotherapy: Extracorporeal Depletion of Biotinylated and 90Y-Labelled Rituximab in Patients with Refractory B-Cell Lymphoma. Can. Biother. Radiopharma., 20, 457466.

Maeda, J., Suhara, T., Zhang, M. R., Okauchi, T., Yasuno, F., Ikoma, Y., Inaji, M., Nagai, Y., Takano, A., Obayashi, S., Suzuki, K. (2004), Novel peripheral benzodiazepine receptor ligand [11C]DAA1106 for PET: An imaging tool for glial cells in the brain. Synapse, 52, 283-291.
Martins, F. P. P., Gutfilen, B. (2002), Estudo da marcação do anticorpo monoclonal OKT3 com tecnécio-99m: aplicações clinicas. Radiol. Bras., 35, 286.

Martins F. P. P., Souza S. A. L., Gonçalves R. T., Fonseca L. M. B., Gutfilen B. (2004), Preliminary Results of [99mTc]OKT3 Scintigraphy to Evaluate Acute Rejection in Renal Transplants. Transplant. Proc., 36, 2664- 2667.

Mason, J. C., Haskard, D. O. (1994), The clinical importance of leucocytes and endothelial cell adhesion molecules in inflammation. Vasc. Med. Rev., 5, 249-275.

Miot-Noirault, E., Perin, F., Routledge, L., Normier, G., Le Pape, A. (1996), Macrophage targeting with technetium-99m labelled J001 acylated polygalactoside for scintigraphy of inflammation: optimization and assessment of imaging specificity in experimental arthritis. Eur. J. Nucl. Med., 23, 61-68.

Nagy, Z. A., Hubner, B., Löhning, C., Rauchenberger, R., Reifert, S., Thomassen, Wolf, E., Zahn, S., Leyer, S., Schier, E. M., Zahradnik, A., Brunner, C., Lobenwein, K., Rattel, B., Stanglmaier, M., Hallek, M., Wing, M., Anderson, S., Dunn, M., Kretschmar, T., Tesar, M. (2002), Fully human, HLA-DR-specific monoclonal antibodies efficiently induce programmed death of malignant lymphoid cells. Nat. Med., 8, 801-807.

Nijhof, M. W., Oyen, W. J. G., van Kampen, A., Claessens, R. A., van der Meer, J. W., Corstens, F. H. M. (1997), Evaluation of infections of the locomotor system with indium-111-labelled human IgG scintigraphy. J. Nucl. Med., 38, 1300-1305.

Olszewski, A. J., Grossbard, M. L. (2004), Empowering targeted therapy: lessons from rituximab. Sci. STKE 2004, 241, 30.

Ortapamuk, H., Hosal, B., Naldoken, S. (2002), The role of Tc-99m polyclonal human immunoglobulin $\mathrm{G}$ scintigraphy in Graves' ophthalmopathy. Ann. Nucl. Med., 16, 461-465.

Orthoclone, OKT ${ }^{\circledR} 3$ (muromonab-CD3) package insert. Raritan, New Jersey, USA: Ortho Biotech Products; revised November, 2004.

Ouchi, Y., Yoshikawa, E., Sekine, Y., Futatsubashi, M., Kanno, T., Ogusu, T., Torizuka, T. (2005), Microglial activation and dopamine terminal loss in early Parkinson's disease. Ann. Neurol., 57, 168-175.

Perin, F., Pittet, J. C., Hoffschir, D., Normier, G., Binz, H., Le Pape, A. (1993), Scintigraphy potential of J001X acylated polygalactoside for imaging inflammatory lesions in pigs. Nucl. Med. Biol., 20, 963-971.

Rau, R. (2002), Adalimumab (a fully human antitumour necrosis factor a monoclonal antibody) in the treatment of active rheumatoid arthritis: the initial results of five trials. Ann. Rheum. Dis., 61 (Suppl II), ii70-ii73. 
Reff, M. E., Carner, K., Chambers, K. S., Chinn, P. C., Leonard, J. E., Raab, R., Newman, R. A., Hanna, N., Anderson, D. R. (1994), Depletion of B cells in vivo by a chimeric mouse human monoclonal antibody to CD20. Blood, 83, 435-445.

Rennen, H. J. J. M., Boerman, O. C., Oyen, W. J. G., Corstens, F. H. M. (2001), Imaging infection/inflammation in the new millennium. Eur. J. Nucl. Med., 28, 241-252.

Rimsza, L. M., Farinha, P., Fuchs, D. A., Masoudi, H., Connors, J. M., Gascoyne, R. D. (2007), HLA-DR protein status predicts survival in patients with diffuse large B-cell lymphoma treated on the MACOP-B chemotherapy regimen. Leuk Lymphoma, 48, 542-546.

Rituxan $^{\circledR}$ (Rituximab), package insert. Genetech Inc., San Francisco, CA; revised February 21, 2007.

Robb, R. J., Mayer, P. C., Garlick, R. (1985) Retention of biological activity following radioiodination of human interleukin-2: comparison with biosynthetically labelled growth factor in receptor binding assay. J. Imuunol. Meth., 81, 15-30.

Schmitz, A., Risse, J. H., Grunwald, F., Gassel, F., Biersack, H. J., Schmitt, O. (2001), Fluorine-18 fluorodeoxyglucose positron emission tomography findings in spondylodiscitis: preliminary results. Eur. Spine. J., 10, 534-539.

Signore, A., Chianelli, M., Annovazzi, A., Bonanno, E., Spagnoli, L. G., Pozzilli, P., Pallone, F., Biancone, L. (1999a), ${ }^{123}$ I-labelled interleukin-2 scintigraphy for the in vivo assessment of intestinal mononuclear cell infiltration in Crohn's disease. J. Nucl. Med., 41, 242249.

Signore, A., Chianelli, M., Annovazzi, A., Rossi, M., Maiuri, L., Greco, M., Ronga, G., Britton, K. E., Picarelli, A. (1999b), Imaging active lymphocytic infiltration in Coeliac disease with 123I-Interleukin-2 and its response to diet. Eur. J. Nucl. Med., 27, 18-24.

Signore, A., Picarelli, A., Chianelli, M., Biancone, L., Annovazzi, A., Tiberti, C., Anastasi, E., Multari, G., Negri, M., Pallone, F., Pozzilli, P. (1996), 123IInterleukin-2 scintigraphy: a new approach to assess disease activity in autoimmunity. J. Pediatric Endocrinol. Metab., 9 (Suppl 1), 139-144.

Signore, A., Procaccini, E., Annovazzi, A., Chianelli, M., van der Laken, C., Mire-Sluis, A. (2000), The developing role of cytokines for imaging inflammation and infection. Cytokine, 12, 1445-1454.

Smith, K. A. (1988), Interleukin-2: inception, impact and implications. Science, 240, 1169-1176.
Stalteri, M. A., Mather, S. J. (1996), Technetium-99m labelling of the antitumour antibody PR1A3 by photoactivation. Eur. J. Nucl. Med., 23, 178-187.

Stashenko, P., Nadler, L. M., Hardy, R., Schlossman, S. F. (1980), Characterization of a human B lymphocyte-specific antigen. J. Immunol., 125, 16781685.

Stopar, T. G., Mlinaric-Rascan, I., Fettich, J., Hojker, S., Mather, S. J. (2006), 99mTc-rituximab radiolabelled by photo-activation: a new nonHodgkin's lymphoma imaging agent. Eur. J. Nucl. Med., 33, 53-59.

Stumpe, K. D., Zanetti, M., Weishaupt, D., Hodler, J., Boos, N., Von Schulthess, G. K. (2002), FDG positron emission tomography for differentiation of degenerative and infectious endplate abnormalities in the lumbar spine detected on MR imaging. A.J.R. Am. J. Roentgenol., 179, 1151-1157.

Tedder, T. F., Boyd, A. W., Freedman, A. S. Nadler, L. M., Schlossman, S. F. (1985), The B cell surface molecule B1 is functionally linked with B-cell activation and differentiation. J. Immunol., 135, 973979.

Venjamuri, S., Hall, A. V., Solanki, K. K., Bomanji, J., Siraj, Q., O'Shanghnessy, E. Das, S. S., Britton, K. E. (1996), Comparison of ${ }^{99 m}$ Tc infecton imaging with radiolabelled white-cell imaging in the evaluation of bacterial infection. Lancet, 347, 233-235.

Wang, X. J., Lin, B. H., Yang, Z., Ouyang, T., Li, J. F., Xu, B., Zhang, Y., Zhang, M. Y. (2006), Preliminary study on a new sentinel lymphoscintigraphy agent 99mTc-Rituximab for breast patient. Zhonghua Zhong Liu Za Zhi (Chinese. J. Oncol.), 28, 200-203.

Zhang, M. R., Maeda, J., Ogawa, M., Noguchi, J., Ito, T., Yoshida, Y., Okauchi, T., Obayashi, S., Suhara, T., Suzuki, K. (2004), Development of a New Radioligand, N-(5-Fluoro-2-phenoxyphenyl)-N-(2[18F]fluoroethyl-5-ethoxybenzyl)acetamide, for PET Imaging of Peripheral Benzodiazepine Receptor in Primate Brain. J. Med. Chem., 47, 2228-2235.

Received: July 31, 2007; Revised: August 08, 2007; Accepted: August 10, 2007. 